were grown in boxes of dung and sheltered during cold days with thin plates of Lapis specularia. Lettuce is mentioned by Charlemagne, and in the time of Albertus Magnus (1193-1280) it was grown throughout the year. From the Norman invasion of England until the middle of the sixteenth century, gardening appears to have been very greatly subordinated by the political unrest. Its development in the serenteenth century was closely bound with the herbalists Gerard and Parkinson. The initiation of French gardening, involving the protection of early plants with glass cloches, appears to have been due to Jean de la Quintinye in the second half of the seventeenth century, and crops were then brought to maturity upon hotbeds. Joln Evelyn, John Woolridge and Prof. Bradley added their quota of horticultural development in the succeeding hundred years, to be followed by J. C. Loudon. French gardening declined in the later half of the nineteenth century, however, only to give place to the more workable and convenient methods of glasshouse culturo which provide our present supplies of extra-seasonal vegetables.

\section{A New Cyclotron}

THE cyclotron constructed in the workshop of the Physics Department of Purduo University, Indiana, is described in the November issue of the Journal of the Franklin Institute by the five members of the staff who designed it. So far as possible standard materials available in industry have been used in its construction. The magnet is of low carbon steel $3 \mathrm{~m}$. long and $2 \mathrm{~m}$. high, and the pole pieces of special shape $1 \mathrm{~m}$. diameter. The magnetizing coils are of thin copper tube through which cold water circulates. Each coil is square in section with side $30 \mathrm{~cm}$. The oscillator is of the tuned grid tuned plate type, of frequency $10.9 \mathrm{MIc}$., with neutralizing condensers. It takes 3 amperes at 8,500 volts. The chamber is of the Berkeley type with floor and top of steel plate $3 \mathrm{~cm}$. thick with special arrangements for controlling the bending due to external pressure, which has been found to increase the beam intensity. The ions are supplied by an arc near the centre of the cyclotron. The instrument yields 16.5 million volts for $\mathrm{He}^{+}+$ ions.

\section{The National Institute for Research in Dairying}

The annual report of the National Institute for Research in Dairying, Reading, covering the year ending September 30, 1938, has just been published; this seems an unnecessarily long delay. Develop. ments, administrative matters and changes in the staff are outlined, and a summary is given of the research work that has been carried out in the various departments. Among tho last named is an investigation in the Department of Physiology and Biochemistry on the nutritive value of sprayr-dried milk, roller-dried milk and evaporated milk. The biological values of the proteins, and the content of vitamin $A$ and of vitamin $C$ are much the same for all three products, but vitamin $B$ is much reduced in the evaporated milk--to half that present in the other two. The results show that properly dried milk retains to a remarkable extent the nutritive value of the raw product and that modern methods of spray drying yield a powder of high nutritional quality. An appeal is made for donations to meet the cost of new buildings which are urgently needed to reliove the acute congestion in the existing laboratories.

\section{International Society of Medical Hydrology}

A MEETIsG of the general purposes committee of the International Society of Medical Hydrology was held in London on November 17 last to deal with emergency measures made necessary by the War, and also by the death of the Society's chairman of council, Dr. E. P. Poulton. Dr. J. Barnes Burt was elected interim chairman of council, and four addi. tional vice-chairmen, all in countries 'neutral' in the present conflict, were appointed. It was further resolved that the cash balance remaining should be set aside for reconstruction of the Society after the War, and the general secretary was given indefinite leave of absence without pay and instructed to close the London office. The Society's address will be, until further notice, that of the honorary treasurer, Dr. G. D. Kersley, 6 The Circus, Bath.

\section{Medical Organizations of India}

Tue medical organizations of all-India are reviewed by Major-General Bradfield, director-general of the Indian Medical Service, in a volume of 658 pages entitled "An Indian Medical Review" (Government of India Press, New Delhi, 1938). Administrative organization and the medical profession and services, hospitals and nursing, maternity service and pharmacy, and medical education and research, aro all surveyed in the first 280 pages, the remainder of the book containing full statistics of hospitals, dispensaries and other medical institutions. This volume should prove a useful supplement to the "Annual Report of the Public Health Commissioner with the Government of India".

\section{The Night Sky in January}

Durisg this month, the night shortens in the latitude of London by 1 hour 10 minutes, reckoning from sunset to sunrise. The moon is new on January 9, and full on January 24. Occultations of stars by the moon include three stars of magnitude $3-4$ of the Hyades cluster which precedes Aldebaran. The disappearances as seen from Greenwich take place on January 20 as follows: $\delta$ Tauri at $21 \mathrm{~h} .37 \cdot 9 \mathrm{~m}$. at position angle $107^{\circ}$ from the north point of the moon's disk: 64 Tauri at $22 \mathrm{~h} .31 \cdot \mathrm{lm}$. at $142^{\circ}$ and 68 Tauri at $23 \mathrm{~h} .29 \cdot 0 \mathrm{~m}$. at $16^{\circ}$. On January 23 , $\lambda$ Geninorum $(3.6 \mathrm{~m}$.) is occulted at $20 \mathrm{~h} .20 .9 \mathrm{~m}$. at $121^{\circ}$. There is a fine array of planets in the evening sky-Venus, Mars, Jupiter and Saturn-whilst Uranus, a faint 6th magnitude object, is in Aries near the 6th magnitude star 53 Arietis. At the beginning of the month, MIars is overtaking Jupiter in the eastward shift of the two planets among the stars by about $\frac{1}{2}^{\circ}$ a day, and on January 7 at $15 \mathrm{~h}$. there is a conjunction, the geocentric distance between 
the two objects being $1 \cdot 2^{\circ}$. It is interesting to compare the colours and magnitudes of Mars and Jupiter when close together. Lunar conjunctions with the planets occur as follows: Jan. 8d. 10h. with Mercury ; 12d. 13h. with Venus; 15d. 22h. with Jupiter; 16d. 7h. with Mars; 17d. 17h. with Saturn. In midJanuary at about $22 \mathrm{~h}$, the southern meridian is kright with the stars of Taurus, Auriga, Orion, Gemini, Canis Minor and Canis Major. The Great Nebula of Orion shows to the naked eye as a hazy patch. The photographic plate is required to show the nebulosities, which, enveloping the Pleiades, are but the central condensation, according to Barnard, of an enormous nebula covering at least 100 square degrees. Not far from $\varphi$ Tauri is a dark nebulous region giving the strongest proof, according to the same authority, of the existence of obscuring matter in space. Near $\zeta$ Tauri is the so-called Crab Nebula, which is No. 1 in the catalogue of 103 nebula drawn up in $\mathbf{1 7 8 1}$ by Messier for his own use when searching for and identifying comots.

\section{Announcements}

Trie Royal Meteorological Society's Symons Gold Medal for 1940 has been awarded to Prof. Dr. J. Bjerknes of the Geofysiske Institutt, Bergen.

THE Secretary for Mines has appointed Lord Cadman to be honorary adviser on oil, and Sir Harold Hartley to be honorary adviser on the development of home-produced fuels.

THE Minister of Health and the Secretary of State for Scotland havo jointly appointed Dr. Edward Ellice Henderson, a medical officer of the Ministry of Health, to undertake the duties of inspector of anatomy in England, Scotland and Wales.

IT is of interest to put on record that MajorGeneral A. G. L. MeNaughton, commanding the Canadian Active Service Force which has recently landed in Great Britain, is a science graduate of McGill University and was president during 1935-39 of the National Research Council of Canada.

The popular series of Gaumont British Instruc. tional Films called "Secrets of Life" have now been made in colour using the Dufay process, and three of the present series of six were demonstrated at Film House on December 20. The valuable teaching aid that colour gives in educational films was apparent, and although many technical difficulties remain to be overcome, these films portraying the life-history of the burnet moth, the genetics of the lupin, the habits of badgers and other subjects have already reached a high level of efficiency. Mr. Oliver Pike's photographs in the badger film represent a real contribution to natural history.

Dr. Georae W. Corner, who has occupied the chair of anatomy in the University of Rochester (New York) since 1924, has been appointed director of the Department of Embryology, Carnegie Institution, Washington, D.C. Ho succeeds Dr. George Streeter, who has done so much to give the Department of Embryology of tho Carnegio Institution its high place in the estimation of embryologists in all parts of the world. Dr. Streeter, who now retires, succeeded the first director-the late Prof. Franklin Mall. Dr. Corner's appointment has the warm approval of his fellow embryologists.

Sir WaLter Laxgdon-Brown has been appointed president of the British Social Hygiene Council in succession to the Right Hon. L. S. Amery, M.P.

A Crmb Guidance Clinic providing a limited service is available at Guy's Hospital for the hospital area.

According to official statistics of the last fifty years, there has been a considerable reduction in the tuberculosis mortality in Germany. In women the mortality per 100,000 has fallon from $28 \cdot 4$ to $6 \cdot 4$ and in men from $34 \cdot 2$ to $7 \cdot 8$.

According to the latest provisional figures issued by the United States Bureau of Census, the infant mortality reached a record low level of 50.9 per 1,000 live births in 1938, as compared with 54.4 in 1937. The rato has been decreasing steadily for twenty years: in 1915, when the birth rogistration area was established, it was $99 \cdot 9$.

Tre Pan-American Congress of Rural Hygiene organized by the Government of Mexico and the International Congress of Otorhinolaryngology which were to have been held in 1940 have been postponed indefinitely owing to the War.

WE have received the first annual report of the Council of the Institute of Medical and Veterinary Science, Adelaide, South Australia. Now laboratories of the Institute have recently been opened, of which an illustration is given. The Institute provides for the Adelaide Hospital, and for practitioners resident in the district, services in pathology, bacteriology and biochemistry, as well as work in veterinary pathology. A summary is given of the research work conducted by the staff of the Institute. This Institute was described by Sir Charles Martin in Nature of August 26, p. 392.

Chronica Botanica, the international botanical journal published under the editorship of Dr. Frans Verdoorn, is to appear weckly from January 1940. This journal is unique among scientific journals, and contains digests, correspondence, quotations, comments on international affairs, news of institutions, experiment stations, gardens, societies, etc., personal notes and news, reviews, etc. The annual subscription will bo 15 guilders, including postage. Further information can bo obtained from Chronica Botanica, P.O. Box 8, Loyden, Holland. 